\title{
Influence of Maternal and Postweaning Linseed Dietary Supplementation on Growth Rate, Lipid Profile, and Meat Quality Traits of Light Sarda Lambs
}

\author{
Massimo Trabalza-Marinucci, Laura Mughetti, David Ranucci, Gabriele Acuti, \\ Oliviero Olivieri, Dino Miraglia, and Raffaella Branciari
}

Department of Veterinary Medicine, University of Perugia, Via San Costanzo 4, 06126 Perugia, Italy

Correspondence should be addressed to Massimo Trabalza-Marinucci; massimo.trabalza@unipg.it

Received 23 October 2015; Accepted 15 February 2016

Academic Editor: Brigitte Picard

Copyright (C) 2016 Massimo Trabalza-Marinucci et al. This is an open access article distributed under the Creative Commons Attribution License, which permits unrestricted use, distribution, and reproduction in any medium, provided the original work is properly cited.

\begin{abstract}
The effects of dietary extruded linseed (EL) on growth performance, meat quality, and lipid profile of Semimembranosus and Longissimus lumborum muscles of 81 Sarda lambs were studied in a $3 \times 3$ design: EL content $(0 \%, 10 \%$, and $20 \%)$ of maternal dietary concentrate fed from $20 \mathrm{~d}$ to parturition to $60 \mathrm{~d}$ of lactation and EL content $(0 \%, 10 \%, 20 \%)$ of lamb concentrate fed after weaning for $30 \mathrm{~d}$. The basal diet was composed of alfalfa and meadow hay during pregnancy and alfalfa hay during lactation. At slaughter, carcass and meat quality were evaluated. Sensory quality of Semimembranosus from $0 \%$ and 20\% EL lambs was assessed. Both maternal and postweaning diets affected growth performance, with higher body weights recorded with the 10\% EL concentrate. Carcass and meat quality were not affected by diet. Saturated and monounsaturated FA decreased and n-3 polyunsaturated FA increased with increasing EL content in lamb diet. An increase in vaccenic and rumenic acid was associated with the EL content of the maternal diet. Both diets increased the n-6/n-3 FA ratio. No differences in acceptability were detected by consumers among groups. It is concluded that EL supplementation and early life nutrition can influence performance and FA metabolism in growing lambs.
\end{abstract}

\section{Introduction}

Ruminant meats have been associated with an increase in the risk of cardiovascular diseases, due to their high content of saturated fatty acids (SFA) [1, 2]. However, ruminant meats may also be a good dietary source of some nutrients with health benefits including a number of fatty acids (FA) such as long chain-polyunsaturated FA (LC-PUFA), n-3 PUFA in particular, and conjugated linoleic acid (CLA) isomers. The decrease of SFA and the increase of health-beneficial FA have been a main topic of ruminant meat research. Strategies for enrichment of lamb meat in n-3 PUFA have included diets enriched with fish products or with oilseeds such as linseed [ 3 , 4]. However, many of the studies have focused on the effects of diets fed to growing animals [5-8]. Only a few studies, mainly addressed to laboratory and monogastric species [912], have investigated the effects of maternal consumption of LC-PUFA enriched diets during gestation and lactation on later performance and metabolism in the offspring. A correct status of LC-PUFA and a high ratio of n-3/n-6 PUFA are believed to be beneficial for growing animals that are facing the weaning and the derived stress. Since the quality of dietary fat can modify the cellular and lipid metabolism, it is expected that a maternal diet rich in n-3 PUFA can influence the lipid metabolism of the offspring in later life [10, 12-14]. However, this mechanism has not been fully explored. Hoile et al. [11] have demonstrated that maternal fat intake can alter the epigenetic regulation of Fads 2 transcription in rats. In goats, high $\alpha$-linolenic acid diets were able to upregulate the peroxisome proliferator-activated receptors (PPAR- $\alpha$ ) gene and downregulate the stearoyl-CoA-desaturase gene compared to control diets with low ALA content [15]. In a study conducted with Vendeen sheep, extruded linseed(EL-) enriched concentrates used in both maternal and lamb 
weaning diets were able to increase the proportions of $\alpha$ linolenic acid (ALA) and n-3 PUFA in tissues [16]. However, this experiment started three weeks after lambing and the lambs were assigned to the experimental diets when they were still suckling from their mothers.

In the Italian rearing systems, lambs are either fed maternal milk alone and slaughtered at 30-45 d of age or reared on a forage and concentrate diet and slaughtered before 4 months of age. Sarda is the most common dairy sheep breed found in Italy. In this work we investigated the effects of the interaction between maternal and postweaning diets, both enriched with EL, on growth rate, lipid profile, and sensory characteristics of meat from light Sarda lambs.

\section{Materials and Methods}

2.1. Experimental Design, Animals, and Diets. The present study was carried out in the "Azienda Zootecnica Didattica" of the Department of Veterinary Medicine, University of Perugia. Three weeks before their expected date of parturition, 60 Sarda ewes were randomly divided into three groups of equal size, balanced for body weight (BW: $45.5 \pm 1.2 \mathrm{~kg}$ ) and body condition score (2.9 \pm 0.1$)$ [17], and fed isoenergetic and isonitrogenous concentrates. The three concentrates were as follows: a control concentrate (CTR), without EL, and two experimental concentrates which contained, respectively, $100 \mathrm{~g} / \mathrm{kg}$ (EL-10) and $200 \mathrm{~g} / \mathrm{kg}$ (EL-20) of ground EL. Experimental diets were administered up to 60 days postpartum, when the lambs were weaned. Animals were fed 400 to 800 g per head per day of concentrate (during late pregnancy and early lactation, resp.), which was administered in two equal portions during the day. All the offered concentrate was consumed by the sheep during the whole length of the experiment. The concentrate composition is presented in Table 1. Alfalfa (crude protein: 12.4\%; neutral detergent fiber: $44.5 \%$; ash: $7.5 \%$ ) and meadow (crude protein: $9.1 \%$; neutral detergent fiber: $56.2 \%$; ash: $7.3 \%$ ) hay were provided in box feeders ad libitum. Average hay dry matter intake (measured over a period of $3 \mathrm{~d} /$ week as the difference between forage distributed and refusal) was $1.25 \mathrm{~kg} /$ ewe/day during pregnancy and $1.53 \mathrm{~kg} /$ ewe/day during lactation and was not affected by the dietary treatment.

Twinning rate was $38.3 \%$. Lambs were suckled by their mothers up to 8 weeks of age and were housed in a stable with unlimited access to an outdoor paddock with no pasture available. At weaning (initial BW: $15.3 \pm 0.8 \mathrm{~kg}$ ) 81 lambs were randomly allocated to three groups of 27 animals each according to the EL content in the concentrate. The groups were balanced for sex, age, mothers' dietary treatment, and ram used in the breeding group. Lamb experimental concentrates were the same as the ones used in the ewes' diets (CTR, EL-10, and EL-20) and were offered daily at a rate of 50 and $150 \mathrm{~g} /$ head during the first $10 \mathrm{~d}$ and the remaining $20 \mathrm{~d}$ of the trial, respectively. The concentrate was entirely consumed by the animals. Lambs were offered the ewes' alfalfa hay ad libitum. The estimated hay dry matter intake averaged 0.55 , 0.53, and $0.52 \mathrm{~kg} / \mathrm{lamb} /$ day for CTR, EL-10, and EL-20 groups, respectively.
TABLE 1: Ingredients and chemical composition of the experimental concentrates fed during the trial.

\begin{tabular}{|c|c|c|c|}
\hline \multirow{2}{*}{ Item } & \multicolumn{3}{|c|}{ Concentrates $^{1}$} \\
\hline & CTR & EL-10 & EL-20 \\
\hline \multicolumn{4}{|l|}{ Raw materials (\% as fed basis) } \\
\hline Soybean meal & 188.2 & 124.0 & 60.8 \\
\hline Corn meal & 335.9 & 157.0 & 20.0 \\
\hline Barley grain & 50.0 & 50.0 & 20.0 \\
\hline Wheat bran & 162.6 & 303.1 & 578.2 \\
\hline Wheat flour shorts & 200.0 & 200.0 & 57.4 \\
\hline Extruded linseed & - & 100.0 & 200.0 \\
\hline Molasses & 20.0 & 20.0 & 20.0 \\
\hline Calcium carbonate & 16.9 & 19.7 & 21.6 \\
\hline Bicalcic phosphate & 9.4 & 4.2 & - \\
\hline Sodium bicarbonate & 5.0 & 5.0 & 5.0 \\
\hline Sodium chloride & 5.0 & 5.0 & 5.0 \\
\hline Vitamin and mineral premix ${ }^{2}$ & 5.0 & 5.0 & 5.0 \\
\hline Bonding agent & - & 5.0 & 5.0 \\
\hline Magnesium oxide & 2.0 & 2.0 & 2.0 \\
\hline \multicolumn{4}{|l|}{ Analysed nutrients ${ }^{3}$ (g/100 g) } \\
\hline $\mathrm{DM}$ & 89.12 & 88.66 & 89.12 \\
\hline $\mathrm{CP}$ & 15.99 & 15.85 & 16.01 \\
\hline $\mathrm{CF}$ & 2.53 & 6.93 & 10.23 \\
\hline Ash & 6.83 & 7.25 & 7.83 \\
\hline NDF & 16.33 & 19.23 & 24.34 \\
\hline $\mathrm{ADF}$ & 5.01 & 6.21 & 7.99 \\
\hline Lignin & 1.12 & 1.46 & 2.31 \\
\hline Calcium & 1.28 & 1.35 & 1.41 \\
\hline Phosphorus & 0.35 & 0.40 & 0.41 \\
\hline $\mathrm{C} 16: 0$ & 15.50 & 10.11 & 8.90 \\
\hline C18:0 & 2.09 & 2.97 & 3.42 \\
\hline C18:1 c9 & 22.78 & 18.11 & 17.59 \\
\hline $\mathrm{C} 18: 2 \mathrm{c} 9, \mathrm{cl} 2$ & 54.07 & 32.64 & 23.86 \\
\hline $\mathrm{C} 18: 3$ c9, c12, c15 & 5.32 & 35.22 & 45.41 \\
\hline
\end{tabular}

${ }^{1}$ CTR: diet without extruded linseed; EL-10: diet containing $100 \mathrm{~g} / \mathrm{kg}$ of extruded linseed; EL-20: diet containing $200 \mathrm{~g} / \mathrm{kg}$ of extruded linseed.

${ }^{2}$ Mineral and vitamin premix supplied (per kg of final diet): Co, $0.30 \mathrm{mg}$ (2 $\left.\mathrm{CoCO}_{3} ; 3 \mathrm{Co}(\mathrm{OH})_{2} \mathrm{H}_{2} \mathrm{O}\right) ; \mathrm{Zn}, 50.00 \mathrm{mg}(\mathrm{ZnO}) ; \mathrm{Fe}, 15.00 \mathrm{mg}\left(\mathrm{FeCO}_{3}\right) ; \mathrm{Mn}$, $30.00 \mathrm{mg}(\mathrm{MnO}) ; \mathrm{Se}, 0.60 \mathrm{mg}\left(\mathrm{Na}_{2} \mathrm{SeO}_{3}\right) ; \mathrm{I}, 1.00 \mathrm{mg}\left(\mathrm{Ca}\left(\mathrm{IO}_{3}\right)_{2}\right)$; vitamin A, $50,000 \mathrm{IU}$ (retinylacetate); cholecalciferol, 3,000 IU; vitamin E, $50.00 \mathrm{mg}(\alpha$ tocopherol acetate).

${ }^{3}$ DM: dry matter; CP: crude protein; CF: crude fat; NDF: neutral detergent fibre; and ADF: acid detergent fibre.

At the end of trial, lambs were transported to the abattoir. After weighing, to obtain the live slaughter weight, lambs were stunned and slaughtered by exsanguination.

2.2. Recordings, Sampling, and Analytical Procedures. During the trial, samples of experimental concentrates were collected weekly and analysed for chemical composition following AOAC methods [18-21]. The methods of Van Soest et al. [22] were used in the analyses of NDF (not assayed with a heat 
stable amylase), ADF, and lignin (sa). Sodium sulphite was used in the NDF procedure, and both NDF and ADF were expressed inclusive of ash.

Lambs were weighed at birth, at weaning, and at slaughter. Carcasses were weighed after 24 hours of chilling, before dissection, to obtain the cold carcass weight. Ten carcasses of each group were randomly selected for further analyses.

The $\mathrm{pH}$ was assessed 15 minutes after slaughter on Longissimus lumborum (LL) muscle (space between last thoracic and first lumbar vertebrae) and on Semimembranosus (SM) muscle using a puncture electrode probe connected to a portable $\mathrm{pH}$ meter (model MP120, Mettler Toledo Inc., Columbus, USA). The carcasses were then chilled at a temperature of $5^{\circ} \mathrm{C}$. The entire LL (between the 2nd-3rd last thoracic vertebrae and the 4th-5th lumbar vertebrae) and SM muscles from the right side of the carcasses were removed $24 \mathrm{~h}$ postmortem and representative subsamples of the muscles were obtained to assess ultimate $\mathrm{pH}$, color, cooking loss, Warner-Bratzler shear (WBS) force, proximate composition, cholesterol content, and FA profile.

Meat color was estimated in 6 different surface points of a $2.5 \mathrm{~cm}$ thick sample of both muscles (MLS on the 12th rib) subjected to a $1 \mathrm{~h}$ blooming period at $4^{\circ} \mathrm{C}$ after cutting using a tristimulus colorimeter (CR-400 Chroma Meter, Minolta Ltd., Osaka, Japan) and expressed as CIE LAB $L^{*} a^{*} b^{*}$ values [23]. For the cooking loss determination, LL and SM samples $(1.5 \mathrm{~cm}$ thick) were weighed and placed in thinwalled plastic bags in a water-bath at $80^{\circ} \mathrm{C}$. After $1 \mathrm{~h}$ the samples were removed from the water-bath, cooled in cold water, dry blotted, and weighed. Cooking loss was calculated as the difference in sample weight before and after cooking, expressed as a percentage of the initial sample weight [24]. The WBS measurements of the cooked LL and SM samples (same samples as used for cooking loss determination) were obtained with a WBS device fitted to an Instron Universal Testing Machine (Model 1011) with a $50 \mathrm{~kg}$ load cell (Instron, Norwood, MA, USA). These readings were taken within $1 \mathrm{~h}$ of the final weight measurement (cooking loss determination). Three cylindrical cores were cut from each muscle using a $1,2265 \mathrm{~cm}$ diameter core. Samples were randomly removed from the center of each muscle. The maximum WBS values $\left(\mathrm{kg} / \mathrm{cm}^{2}\right)$ required to shear a cylindrical core of cooked muscle, perpendicular to the muscle fiber longitudinal axis (at a crosshead speed of $100.0 \mathrm{~mm} / \mathrm{min}$ ), were recorded for each core in triplicate and the mean was calculated for each muscle [24].

Proximate composition of LL and SM muscles samples was analysed according to AOAC [21]. Total cholesterol of the muscles was determined by colorimetric kit (Cat. number 10139050035: Cholesterol Biopharm, Germany) with a spectrophotometer (Ultrospec 2011 pro, Amersham Pharmacia Biotech, Milan, Italy) at a wavelength of 405 .

Milk FA were extracted according to the Röse-Gottlieb method [18], while meat FA were extracted according to the Bligh and Dyer [25] method. The transmethylation was performed according to the procedure of Branciari et al. [26]. Methyl esters were separated and quantified using a VARIAN 3400 gas chromatograph equipped with a flame ionization detector (FID) and a split-splitless injector. Analyses were performed with CP-Select CB for FAME fused silica capillary column $(100 \mathrm{~m} \times 0.25 \mathrm{~mm}$ i.d., film thickness of $0.39 \mu \mathrm{m}$, J\&W, Agilent technologies, Palo Alto, CA, US). The injection volume was $1 \mu \mathrm{L}$. The carrier gas was high purity helium with flow rate of $1 \mathrm{~mL} / \mathrm{min}$. The injector and detector temperatures were kept at $290^{\circ} \mathrm{C}$. The column oven temperature was programmed at $120^{\circ} \mathrm{C}$ and increased by $3.2^{\circ} \mathrm{C} / \mathrm{min}$ up to $170^{\circ} \mathrm{C}$ and then increased by $2.1^{\circ} \mathrm{C} / \mathrm{min}$ from $170^{\circ} \mathrm{C}$ to $225^{\circ} \mathrm{C}$. Individual FA methyl esters were identified by comparison with a standard mixture containing 37 FAMEs (Supelco, Bellefonte, PA, USA) and other polyunsaturated FAMEs, as cis-11-vaccenic methyl ester, trans-11-vaccenic methyl ester, and methyl cis-7,10,13,16,19-docosapentaenoate (Sigma-Aldrich, Bellefonte, PA, USA). Quantification was carried out using nonadecanoic acid as internal standard (C19:0, Supelco Park, Bellefonte, PA, USA) added to the sample at the time of extraction.

2.3. Sensory Evaluation of Lamb Thigh. Staff and students of the Veterinary Medicine Department of the University of Perugia were recruited as members of a consumer panel. Consumers were asked to complete a questionnaire that included information about age, sex, and the frequency of consumption of lamb meat. In total 100 consumers, aged 18 to 65 , participated in the test. The evaluation was conducted in two different sessions with 60 and 40 consumers in the 1st and 2nd sessions, respectively, and using meat patty samples obtained from the SM muscle after approximately 1 month of frozen storage. Vacuum-packed thighs $(2 \mathrm{~kg})$ were thawed for $36 \mathrm{~h}$ at $+4^{\circ} \mathrm{C}$. Patties were produced from boneless thigh meat obtained from CTR and EL-20 lambs. Thighs were pooled within each group, ground, and formed into $4 \mathrm{~cm}$ diameter patties in a patty machine. Thigh patties from both CTR and EL-20 groups were divided into two subgroups and cooked either without any seasoning or with salt, spices, and olive oil. Patties were placed on steel trays covered with aluminum foil and oven cooked at $170^{\circ} \mathrm{C}(10 \%$ relative humidity) for approximately $2 \mathrm{~h}$. The patties were kept warm until served. Each participant evaluated 4 different patties (CTR and EL20 , both with or without seasoning).

A practicing session was performed before the test to allow consumers to become familiar with the use of the scale and explain the definitions of attributes. Samples were monadically served on white plastic plates identified by three random digit codes. Consumers received no information and were asked to rate sensory attributes (lamb flavour, lamb odour, extraneous flavours, extraneous odours, and overall acceptability) using an unstructured scale (0-9) [27].

2.4. Statistical Analyses. All data were analysed using an ANOVA in the GLM procedure of SAS [28]. The statistical model included maternal diet (CTR, EL-10, and EL-20), lamb diet (CTR, EL-10, and EL-20), muscle type (LL and SM), and their interactions. For the sensory data, the model used included lamb diet (CTR, EL-10, and EL-20), presence of seasoning, and age, gender, and geographical origin of the assessor. Frequency of lamb meat consumption was included as a covariate. The effect of maternal diet was found to be not significant $(P>0.05)$ and was removed from the model. 
Overall differences between the means were evaluated using Tukey's test. Data were reported as least squares means \pm standard error. Differences were considered to be significant when $P \leq 0.05$.

2.5. Ethical Rules. Use and care of animals in this study were in accordance with the European recommendations [29] for the protection of animals used for scientific purposes.

\section{Results and Discussion}

3.1. Milk Composition. Ewe's milk composition was not affected by the dietary treatment and had the following average characteristics: $\mathrm{pH} 6.67 \pm 0.03 ; 4.69 \pm 0.09 \% \mathrm{w} / \mathrm{w}$ lactose; $6.55 \pm 0.10 \% \mathrm{w} / \mathrm{w}$ fat; and $6.01 \pm 0.12 \% \mathrm{w} / \mathrm{w}$ protein (MilkoScan 6000, Foss Electric, Hillerød, Denmark).

EL supplementation reduced the proportions of SFA from C6:0 to C17:0 (Table 2). The level of most 18-carbon FAs (C18:0, C18:1, C18:2, C18:3, and isomers) was influenced by the dietary treatment: in particular, the vaccenic acid (C18:1 t11) percentage increased more than 3 -fold with the EL-20 diet. Stearic acid (C18:0) and oleic acid (C18:1 c9) were also positively influenced by the dietary treatment. A significant increase of some isomers of C18:2 was also observed following EL dietary supplementation. The concentration of rumenic acid (C18:2 c9 t11) showed a trend similar to that of vaccenic acid. An increase in the percentage of ALA values was also found. The arachidonic acid (C20:4 n-6) was the PUFA present in greatest concentration in the CTR milk and decreased with EL supplementation. LC-PUFA n-3 (C20:5, C22:6) percentage in milk was not modified by diet and was below $0.2 \%$. These results showed on the whole that the EL supplementation decreased the percentage of SFA and increased the MUFA and PUFA contents, thus contributing to modifying the $\mathrm{P} / \mathrm{S}$ ratio and the $\mathrm{n}-6 / \mathrm{n}-3$ ratio. These results are in agreement with most data published in the literature $[26,30,31]$.

3.2. Growth Performance. The BW at birth and growth performance of lambs before weaning were not affected by the dietary treatment of the mothers (Table 3). These data are in agreement with Gallardo et al. [32], who examined the performance of Churra lambs slaughtered at a BW of $12 \mathrm{~kg}$ and fed with the milk of ewes receiving linseed oil-enriched (2.6\%) diets. In this experiment, no dietary effects on growth performance were observed.

In contrast, the postweaning growth rate was influenced by both lamb diet and maternal feeding regimen, with the EL-10 treatment being the most effective in improving the performance (Table 3). The intermediate level of dietary EL (and the limited daily intake of concentrate) was possibly able to provide the rumen environment with the optimal amount of lipids and, in the same time, did not impair dry matter degradability. It has been shown that at the highest EL concentration used in this study (20\% of the concentrate) ruminal degradability and milk production can be negatively affected in dairy ewes $[33,34]$. Berthelot et al. [16] evaluated the effects of EL-enriched diets administered to either Vendeen ewes or their lambs in $2 \times 2$ factorial arrangement using lower EL contents in both maternal (12.5\%) and lamb (6\%) concentrates compared to the EL levels used in the present study. In their experiment, no dietary effects were observed on lamb growth performance before and after weaning. When analysing the effects of diets which differed in their n-6/n-3 FA ratio (from 2.3 to 15.6) and included linseed oil, soybean oil, or cottonseed oil, Kim et al. [35] did not report differences in BW variations among experimental groups. In contrast, Ponnampalam et al. [8] examined the effects of different forms of dietary n-3 FA on ewe lambs performance and found that whole linseed added to the diet (10\%) improved carcass yield, feed : weight gain, and final BW. Jerónimo et al. [36] replaced sunflower oil with linseed oil in Merino Branco ram lambs' (average initial BW: $23 \mathrm{~kg}$ ) diets and found a linear increase in live slaughter weight and hot carcass weight. It must be stressed, however, that comparisons should be interpreted with caution since most experimental factors (genotype, diet composition, feed intake, age at the beginning of the trial, average daily gain, and BW at slaughter) markedly differ between the published studies and the present work.

As for the maternal diet effect, a possible epigenetic influence can be hypothesized. There are no experimental data which support this hypothesis in sheep; however, a maternal high-fat diet was shown to increase offspring BW in mice [9]. These BW changes did not correlate with feed or energy intake, but they were rather associated with an epigenetic influence of the GH/IGF-I axis. Indeed, the nutritional status experienced by animals around birth has implications not only for later life risks of developing diseases but also for adipose tissue growth and serum hormone levels [37]. In a series of animal studies, offspring of mothers fed a diet high in calories or high in fat before birth were heavier and had a higher percentage of body fat throughout life [10]. From an evolutionary point of view, the modification of the body size would be a proper response to changing factors such as food availability [38]. In addition, it has been demonstrated in pigs that a maternal diet rich in linseed oil during gestation and lactation can significantly modify the FA composition, structure, and physiology of the offspring ileum, thereby influencing the digestive processes [14].

3.3. Meat Quality Traits. The meat quality results are reported in Table 4. No differences were recorded between the LL and SM muscles for all the parameters examined in this study (data not shown). For this reason, data reported in Tables 4 and 5 were pooled across muscles.

The lamb diet was able to affect meat $\mathrm{pH}$ and lightness values recorded after 24 hours: EL-10 samples showed a slight but significant lower $\mathrm{pH}$ than the EL-20 ones and a higher $L^{*}$ value when compared to CTR. Neither lamb nor maternal diet was able to affect proximal chemical composition and cholesterol content of the meat. These results show that lamb meat has similar chemical traits regardless of the EL content of both maternal and lamb diets. The differences recorded for the $\mathrm{pH}$ and color coordinate values, even if statistically significant, are of limited value. Furthermore, no effects on the other parameters generally linked with muscle $\mathrm{pH}$ and lightness, that is, cooking loss, were observed. These results 
TABLE 2: Effect of linseed supplementation on the fatty acid profile ( $\mathrm{g} / 100 \mathrm{~g}$ of total fatty acids methyl esters) of milk.

\begin{tabular}{|c|c|c|c|c|c|}
\hline & \multicolumn{3}{|c|}{ Maternal diet } & \multirow{2}{*}{ SEM } & \multirow{2}{*}{$P$} \\
\hline & CTR & EL-10 & EL-20 & & \\
\hline C4:0 & 3.38 & 3.61 & 3.39 & 0.081 & 0.433 \\
\hline C6:0 & $2.84^{\mathrm{a}}$ & $2.51^{b}$ & $1.83^{c}$ & 0.108 & $<0.001$ \\
\hline C8:0 & $2.97^{\mathrm{a}}$ & $2.44^{\mathrm{b}}$ & $1.53^{\mathrm{c}}$ & 0.148 & $<0.001$ \\
\hline $\mathrm{C} 10: 0$ & $9.38^{\mathrm{a}}$ & $7.06^{\mathrm{b}}$ & $4.54^{\mathrm{c}}$ & 0.494 & $<0.001$ \\
\hline C11:0 & $0.46^{\mathrm{a}}$ & $0.30^{\mathrm{b}}$ & $0.25^{\mathrm{b}}$ & 0.031 & 0.004 \\
\hline $\mathrm{C} 12: 0$ & $5.23^{\mathrm{a}}$ & $3.91^{\mathrm{b}}$ & $2.51^{\mathrm{c}}$ & 0.272 & $<0.001$ \\
\hline C13:0 & $0.20^{\mathrm{a}}$ & $0.15^{\mathrm{b}}$ & $0.10^{c}$ & 0.010 & $<0.001$ \\
\hline $\mathrm{C} 14: 0$ & $11.46^{\mathrm{a}}$ & $9.64^{b}$ & $8.04^{\mathrm{c}}$ & 0.350 & $<0.001$ \\
\hline C14:1 & $0.27^{\mathrm{a}}$ & $0.17^{\mathrm{b}}$ & $0.11^{\mathrm{c}}$ & 0.016 & $<0.001$ \\
\hline $\mathrm{C} 15: 0$ & $1.18^{\mathrm{a}}$ & $1.15^{\mathrm{a}}$ & $1.03^{\mathrm{b}}$ & 0.021 & 0.003 \\
\hline $\mathrm{C} 16: 0$ & $26.38^{\mathrm{a}}$ & $21.55^{\mathrm{b}}$ & $18.95^{\mathrm{c}}$ & 0.754 & $<0.001$ \\
\hline $\mathrm{C} 16: 1$ & $1.54^{\mathrm{a}}$ & $1.16^{\mathrm{b}}$ & $0.95^{\mathrm{c}}$ & 0.060 & $<0.001$ \\
\hline $\mathrm{C} 17: 0$ & $0.82^{\mathrm{a}}$ & $0.79^{\mathrm{a}}$ & $0.70^{\mathrm{b}}$ & 0.017 & 0.002 \\
\hline $\mathrm{C} 17: 1$ & $0.25^{\mathrm{a}}$ & $0.21^{\mathrm{b}}$ & $0.15^{\mathrm{c}}$ & 0.010 & $<0.001$ \\
\hline C18:0 & $6.58^{\mathrm{a}}$ & $9.38^{\mathrm{b}}$ & $10.90^{c}$ & 0.450 & $<0.001$ \\
\hline C18:1 trans -9 & $0.38^{\mathrm{a}}$ & $0.67^{\mathrm{b}}$ & $0.75^{\mathrm{c}}$ & 0.039 & $<0.001$ \\
\hline C18:1 trans-11 & $2.28^{\mathrm{a}}$ & $4.27^{\mathrm{b}}$ & $7.22^{\mathrm{c}}$ & 0.439 & $<0.001$ \\
\hline C18:1 cis-9 & $14.28^{\mathrm{a}}$ & $17.55^{\mathrm{b}}$ & $18.69^{c}$ & 0.462 & $<0.001$ \\
\hline C18:2 trans -9, trans -12 & $0.04^{\mathrm{a}}$ & $0.14^{\mathrm{b}}$ & $0.35^{\mathrm{c}}$ & 0.033 & $<0.001$ \\
\hline $\mathrm{C} 18: 2$ cis-9, cis-12 & 2.79 & 2.81 & 2.81 & 0.020 & 0.883 \\
\hline C18:2 cis-9, trans-11 & $0.72^{\mathrm{a}}$ & $1.44^{\mathrm{b}}$ & $2.18^{\mathrm{c}}$ & 0.145 & $<0.001$ \\
\hline $\mathrm{C} 18: 3 \mathrm{n}-3$ & $1.14^{\mathrm{a}}$ & $1.53^{\mathrm{b}}$ & $1.96^{\mathrm{c}}$ & 0.082 & $<0.001$ \\
\hline $\mathrm{C} 18: 3 n-6$ & $0.04^{\mathrm{a}}$ & $0.02^{\mathrm{b}}$ & $0.01^{\mathrm{b}}$ & 0.005 & 0.010 \\
\hline C20:0 & 0.28 & 0.28 & 0.27 & 0.004 & 0.694 \\
\hline C20:4 n-6 & $0.16^{\mathrm{a}}$ & $0.07^{\mathrm{b}}$ & $0.03^{\mathrm{b}}$ & 0.014 & 0.002 \\
\hline C20:5 n-3 & 0.04 & 0.05 & 0.05 & 0.004 & 0.586 \\
\hline C21:0 & 0.07 & 0.06 & 0.05 & 0.009 & 0.636 \\
\hline C22:0 & 0.11 & 0.14 & 0.14 & 0.009 & 0.250 \\
\hline C22:5 n-3 & 0.11 & 0.12 & 0.12 & 0.004 & 0.559 \\
\hline $\mathrm{C} 22: 6 \mathrm{n}-3$ & 0.01 & 0.01 & 0.01 & 0.002 & 0.417 \\
\hline C23:0 & 0.07 & 0.06 & 0.06 & 0.010 & 0.984 \\
\hline C24:0 & 0.05 & 0.04 & 0.04 & 0.008 & 0.893 \\
\hline$n-6 / n-3$ & $2.26^{\mathrm{a}}$ & $1.72^{\mathrm{b}}$ & $1.48^{\mathrm{c}}$ & 0.084 & $<0.001$ \\
\hline SFA & $71.46^{\mathrm{a}}$ & $63.07^{\mathrm{b}}$ & $54.32^{c}$ & 1.707 & $<0.001$ \\
\hline PUFA & $5.11^{\mathrm{a}}$ & $6.25^{\mathrm{b}}$ & $7.61^{c}$ & 0.251 & $<0.001$ \\
\hline MUFA & $19.02^{\mathrm{a}}$ & $24.03^{\mathrm{b}}$ & $27.88^{c}$ & 0.885 & $<0.001$ \\
\hline $\mathrm{P} / \mathrm{S}$ & $0.07^{\mathrm{a}}$ & $0.10^{\mathrm{b}}$ & $0.14^{\mathrm{c}}$ & 0.007 & $<0.001$ \\
\hline
\end{tabular}

CTR: diet without extruded linseed; EL-10: diet containing $100 \mathrm{~g} / \mathrm{kg}$ of extruded linseed; EL-20: diet containing $200 \mathrm{~g} / \mathrm{kg}$ of extruded linseed; SFA, saturated fatty acids; MUFA, monounsaturated fatty acids; PUFA, polyunsaturated fatty acids; P/S, polyunsaturated/saturated fatty acids. Means with different superscript within the same row differ.

are in accordance with Moloney et al. [39], who reported similar trends in final $\mathrm{pH}$ and color of SM and LL of lambs fed with linseed oil and $\mathrm{NaOH}$-treated linseed compared to a control group. Similarly, only few differences were reported in the meat composition of Manchego lambs fed with EL, when compared to control animals, and no effects were recorded in the meat of lambs derived from Churra ewes fed with a linseed oil-enriched diet [7, 40]. However, the comparison with data reported by other authors should be carefully considered as the differences between experimental factors can influence the final meat quality characteristics.

The fatty acid composition of the meat was markedly modified by the lamb dietary treatment (Table 5). The proportion of SFA from 12:0 to 17:0 decreased with the EL dietary supplementation. The EL supplementation modified the level of most 18-carbons and increased the stearic acid concentration. A remarkable increase of vaccenic acid, linoleic acid (C18:2 c9 c12), ALA, and the sum of LC-PUFA n-3 was 
TABLE 3: Effect of maternal and lamb postweaning diets on body weight (BW, kg), average daily gain (ADG, kg/die), and cold carcass weight of light Sarda lambs.

\begin{tabular}{|c|c|c|c|c|c|c|c|c|c|}
\hline & \multicolumn{3}{|c|}{ Maternal diet (M) } & \multirow{2}{*}{ SEM } & \multicolumn{3}{|c|}{ Postweaning diet (PW) } & \multirow{2}{*}{ SEM } & \multirow{2}{*}{$\begin{array}{c}P \\
\mathrm{M} \times \mathrm{PW}\end{array}$} \\
\hline & CTR & EL-10 & EL-20 & & CTR & EL-10 & EL-20 & & \\
\hline BW at birth & 3.48 & 3.65 & 3.49 & 0.09 & & & & & \\
\hline BW at weaning & 16.64 & 15.41 & 15.89 & 0.65 & & & & & \\
\hline ADG at weaning & 0.206 & 0.184 & 0.201 & 0.01 & & & & & \\
\hline BW at slaughter & $18.46^{\mathrm{b}}$ & $19.22^{\mathrm{a}}$ & $18.83^{\mathrm{ab}}$ & 0.32 & $18.97^{\mathrm{AB}}$ & $19.32^{\mathrm{A}}$ & $18.58^{\mathrm{B}}$ & 0.29 & 0.281 \\
\hline ADG at slaughter & $0.074^{\mathrm{b}}$ & $0.103^{\mathrm{a}}$ & $0.092^{\mathrm{ab}}$ & 0.01 & $0.090^{\mathrm{AB}}$ & $0.107^{\mathrm{A}}$ & $0.073^{\mathrm{B}}$ & 0.01 & 0.318 \\
\hline Cold carcass weight & $8.96^{\mathrm{b}}$ & $9.29^{\mathrm{a}}$ & $9.04^{\mathrm{ab}}$ & 0.35 & $9.13^{\mathrm{ab}}$ & $9.34^{\mathrm{a}}$ & $9.15^{\mathrm{b}}$ & 0.22 & 0.565 \\
\hline
\end{tabular}

CTR: diet without extruded linseed; EL-10: diet containing $100 \mathrm{~g} / \mathrm{kg}$ of extruded linseed; EL-20: diet containing $200 \mathrm{~g} / \mathrm{kg}$ of extruded linseed.

Means with different superscript within the same row differ. ${ }^{\mathrm{a}, \mathrm{b}} P<0.05 ;{ }^{\mathrm{A}, \mathrm{B}} P<0.01$.

TABLE 4: Effect of maternal and lamb postweaning diets on meat quality traits of light lamb meat.

\begin{tabular}{|c|c|c|c|c|c|c|c|c|c|}
\hline \multirow{2}{*}{ Item } & \multicolumn{3}{|c|}{ Maternal diet (M) } & \multirow{2}{*}{ SEM } & \multicolumn{3}{|c|}{ Postweaning diet (PW) } & \multirow{2}{*}{ SEM } & \multirow{2}{*}{$\begin{array}{c}P \\
\mathrm{M} \times \mathrm{PW}\end{array}$} \\
\hline & CTR & EL-10 & EL-20 & & CTR & EL-10 & EL-20 & & \\
\hline $\mathrm{pH}, 15 \mathrm{~min}$ & 6.64 & 6.68 & 6.59 & 0.04 & 6.61 & 6.62 & 6.68 & 0.05 & 0.384 \\
\hline $\mathrm{pH}, 24 \mathrm{~h}$ & 5.98 & 5.98 & 5.94 & 0.01 & $5.97^{\mathrm{ab}}$ & $5.94^{\mathrm{b}}$ & $6.00^{\mathrm{a}}$ & 0.02 & 0.139 \\
\hline \multicolumn{10}{|l|}{ Raw meat colour } \\
\hline$L^{*}$ & 43.28 & 43.74 & 44.79 & 0.67 & $42.56^{\mathrm{b}}$ & $45.44^{\mathrm{a}}$ & $43.82^{\mathrm{ab}}$ & 0.78 & 0.174 \\
\hline$a^{*}$ & 23.02 & 22.90 & 22.99 & 0.46 & 23.15 & 22.14 & 23.61 & 0.54 & 0.243 \\
\hline$b^{*}$ & 6.44 & 6.47 & 6.68 & 0.24 & 6.43 & 6.38 & 6.79 & 0.29 & 0.489 \\
\hline Cooking loss (\%) & 25.15 & 24.44 & 24.66 & 0.77 & 24.70 & 25.36 & 24.20 & 0.91 & 0.683 \\
\hline WB shear force $\left(\mathrm{N} / \mathrm{cm}^{2}\right)$ & 5.12 & 5.70 & 5.36 & 0.14 & 4.83 & 5.53 & 5.82 & 0.17 & 0.925 \\
\hline Protein (\%) & 19.86 & 18.46 & 19.12 & 0.36 & 19.41 & 18.94 & 19.09 & 0.41 & 0.962 \\
\hline Lipid (\%) & 3.06 & 3.23 & 2.96 & 0.14 & 3.11 & 3.02 & 3.11 & 0.16 & 0.483 \\
\hline Ash (\%) & 1.03 & 1.02 & 1.03 & 0.03 & 1.01 & 1.04 & 1.03 & 0.02 & 0.219 \\
\hline Cholesterol (mg/100 g) & 53.56 & 51.81 & 58.37 & 3.15 & 52.69 & 59.55 & 51.49 & 3.47 & 0.246 \\
\hline
\end{tabular}

CTR: diet without extruded linseed; EL-10: diet containing $100 \mathrm{~g} / \mathrm{kg}$ of extruded linseed; EL-20: diet containing $200 \mathrm{~g} / \mathrm{kg}$ of extruded linseed.

Means with different superscript within the same row differ at $P<0.05$.

induced by the EL-20-enriched diet. These results are in agreement with data obtained by de la Fuente-Vázquez et al. [7] with Manchego lambs fed a concentrate containing $8.7 \%$ EL. In this study a decrease in SFA and MUFA and an increase in PUFA and n-3 FA, C18:3 n-3 in particular (6.5-fold higher compared to control), was observed. The C18:3 n-3 increase is strongly related to the presence of linseed in the diet, with this oilseed being the major dietary source of ALA [41, 42]. As for the long chain n-3 FA, they are recovered only in limited amounts in meat as herbivore diets normally lack these FA (unless marine sources are used). However, results from the present study reinforce the hypothesis that a conversion of ALA to LC-PUFA n-3 through elongation and desaturation in tissues is possible $[16,36]$. The competition between C18:2 n-6 and C18:3 n-3 for desaturation enzymes might affect the conversion to long chain derivatives. The higher proportion of LC-PUFA n-3 in total n-3 FA, compared to the proportion of LC-PUFA n-6 in total n-6 FA, is likely due to the preference of these enzymes for ALA [36].

Table 5 shows the influence of the maternal diet during gestation and lactation on the FA composition of lamb meat. Major effects can be found on SFA (C12:0 and C14:0), MUFA (C18:1 t11), and PUFA, among which rumenic acid
(C18:2 c9 t11) and DHA (C22:6 n-3) increased and C20:4 n6 decreased. To our knowledge, there are no published data concerning the effects of the nutritional status experienced by lambs around birth on the FA metabolism in later life. It has been demonstrated in rats that type of fat fed to mice during gestation and lactation can affect the influence of the dietary fat after weaning on the FA composition of liver and hearth in the offspring [43]. Hoile et al. [11] showed that maternal fat intake in rats was able to modify, through epigenetic regulation, the messenger RNA expression of the genes encoding $\Delta-5$ and $\Delta-6$ desaturases (Fads1 and Fads2) and alter the C20:4 n-6 and C22:6 n-3 status in liver. Even if these results cannot be entirely transposed to the ovine species, it can be hypothesized that a similar epigenetic regulation of the FA synthesis exists. In a recent study with goats fed with a linseed oil-supplemented diet, Ebrahimi et al. $[15,44]$ found an effect on the expression of the PPAR- $\alpha$ gene associated with the regulation of FA metabolic pathway and a downregulation of the SCD gene expression.

3.4. Sensory Analysis. The consumer analysis did not reveal any effect on overall acceptability and sensory properties of meat, except for a higher perception of extraneous flavours 
TABLE 5: Effect of maternal or lamb postweaning diet on the fatty acid composition of light lamb meat ( $\mathrm{g} / 100 \mathrm{~g}$ of fatty acids methyl esters).

\begin{tabular}{|c|c|c|c|c|c|c|c|c|c|}
\hline \multirow{2}{*}{ Item } & \multicolumn{3}{|c|}{ Maternal diet (M) } & \multirow{2}{*}{ SEM } & \multicolumn{3}{|c|}{ Lamb postweaning diet (PW) } & \multirow{2}{*}{ SEM } & \multirow{2}{*}{$\begin{array}{c}P \\
M \times \mathrm{PW}\end{array}$} \\
\hline & CTR & EL-10 & EL-20 & & CTR & EL-10 & EL-20 & & \\
\hline $\mathrm{C} 10: 0$ & 0.109 & 0.137 & 0.108 & 0.021 & 0.145 & 0.115 & 0.095 & 0.026 & 0.181 \\
\hline $\mathrm{C} 12: 0$ & $0.463^{\mathrm{A}}$ & $0.333^{\mathrm{B}}$ & $0.335^{\mathrm{B}}$ & 0.021 & $0.435^{\mathrm{A}}$ & $0.401^{\mathrm{A}}$ & $0.296^{\mathrm{B}}$ & 0.023 & $<0.001$ \\
\hline $\mathrm{C} 14: 0$ & $4.240^{\mathrm{a}}$ & $3.449^{\mathrm{b}}$ & $3.648^{\mathrm{b}}$ & 0.012 & $4.296^{\mathrm{A}}$ & $3.680^{\mathrm{B}}$ & $3.360^{\mathrm{B}}$ & 0.148 & $<0.001$ \\
\hline C14:1 & 0.091 & 0.042 & 0.050 & 0.018 & 0.100 & 0.055 & 0.027 & 0.022 & 0.048 \\
\hline C15:0 & 0.559 & 0.554 & 0.515 & 0.023 & 0.535 & 0.543 & 0.549 & 0.028 & 0.188 \\
\hline $\mathrm{C} 16: 0$ & 21.618 & 20.413 & 20.076 & 0.031 & $22.220^{\mathrm{A}}$ & $20.446^{\mathrm{B}}$ & $19.441^{\mathrm{B}}$ & 0.375 & 0.068 \\
\hline C16:1 & $1.890^{\mathbf{A}}$ & $1.313^{\mathrm{B}}$ & $1.460^{\mathrm{AB}}$ & 0.067 & $1.837^{\mathrm{A}}$ & $1.454^{\mathrm{B}}$ & $1.372^{\mathrm{B}}$ & 0.082 & 0.127 \\
\hline C17:0 & 1.026 & 1.001 & 1.008 & 0.019 & $1.073^{\mathrm{A}}$ & $1.040^{\mathrm{A}}$ & $0.921^{\mathbf{B}}$ & 0.025 & 0.769 \\
\hline $\mathrm{C} 17: 1$ & 0.033 & 0.182 & 0.078 & 0.031 & 0.155 & 0.091 & 0.047 & 0.038 & 0.311 \\
\hline C18:0 & 12.708 & 13.950 & 13.478 & 0.262 & $12.531^{\mathrm{b}}$ & $13.673^{\mathrm{ab}}$ & $13.932^{\mathrm{a}}$ & 0.321 & 0.284 \\
\hline C18:1 t n-9 & 0.161 & 0.073 & 0.124 & 0.043 & 0.076 & 0.206 & 0.077 & 0.055 & 0.256 \\
\hline C18:1 c n-9 & 26.703 & 26.160 & 27.854 & 0.512 & $28.701^{\mathrm{A}}$ & $26.678^{\mathrm{AB}}$ & $25.337^{\mathrm{B}}$ & 0.653 & 0.379 \\
\hline C18:1 t 11 & $3.027^{\mathrm{b}}$ & $3.716^{\mathrm{ab}}$ & $4.040^{\mathrm{a}}$ & 0.165 & $3.050^{\mathrm{b}}$ & $3.810^{\mathrm{ab}}$ & $3.921^{\mathrm{a}}$ & 2.211 & 0.217 \\
\hline $\mathrm{C} 18: 2 \mathrm{t} n-6$ & $0.020^{\mathrm{ab}}$ & $0.018^{\mathrm{b}}$ & 0.061 & 0.011 & 0.034 & 0.009 & 0.055 & 0.014 & 0.199 \\
\hline$C 18: 2 \mathrm{c} n-6$ & 10.613 & 11.115 & 10.221 & 0.399 & $9.210^{\mathrm{B}}$ & $10.877^{\mathrm{AB}}$ & $11.862^{\mathrm{A}}$ & 0.510 & 0.053 \\
\hline $\mathrm{C} 18: 2$ c9,t11 & $1.034^{\mathrm{B}}$ & $1.238^{\mathrm{AB}}$ & $1.456^{\mathrm{A}}$ & 0.071 & 1.139 & 1.293 & 1.296 & 0.090 & 0.829 \\
\hline C18:3 n-3 & 2.422 & 2.759 & 2.669 & 0.087 & $2.041^{\mathrm{C}}$ & $2.714^{\mathrm{B}}$ & $3.096^{\mathrm{A}}$ & 0.107 & 0.066 \\
\hline C20:0 & tr. & tr. & 0.003 & 0.003 & 0.003 & tr. & tr. & 0.003 & 0.883 \\
\hline C21:0 & tr. & 0.006 & 0.021 & 0.008 & 0.021 & 0.006 & tr. & 0.007 & 0.088 \\
\hline C22:0 & tr. & tr. & 0.021 & 0.011 & 0.009 & 0.012 & tr. & 0.014 & 0.916 \\
\hline C20:4 n-6 & $4.347^{\mathrm{A}}$ & $3.774^{\mathrm{AB}}$ & $3.333^{\mathrm{B}}$ & 0.171 & 4.053 & 3.529 & 3.872 & 0.210 & 0.036 \\
\hline$C 20: 3 n-6$ & $0.189^{\mathrm{b}}$ & $0.273^{\mathrm{a}}$ & $0.222^{\mathrm{ab}}$ & 0.015 & 0.188 & 0.233 & 0.263 & 0.019 & 0.107 \\
\hline C23:0 & $0.171^{\mathrm{AB}}$ & $0.207^{\mathrm{A}}$ & $0.121^{\mathrm{B}}$ & 0.017 & 0.161 & 0.133 & 0.203 & 0.020 & 0.001 \\
\hline$C 20: 5 n-3$ & 0.793 & 0.963 & 0.945 & 0.071 & 0.718 & 0.957 & 1.026 & 0.087 & 0.539 \\
\hline$C 22: 5 n-3$ & 1.211 & 1.312 & 1.103 & 0.068 & $1.009^{\mathrm{b}}$ & $1.270^{\mathrm{ab}}$ & $1.346^{\mathrm{a}}$ & 0.083 & 0.553 \\
\hline$C 22: 6 n-3$ & $0.307^{\mathrm{b}}$ & $0.420^{\mathrm{a}}$ & $0.354^{\mathrm{ab}}$ & 0.019 & 0.324 & 0.362 & 0.395 & 0.023 & 0.008 \\
\hline SFA & 40.893 & 40.051 & 39.333 & 0.446 & $41.429^{\mathrm{a}}$ & $40.049^{\mathrm{ab}}$ & $38.799^{b}$ & 0.546 & 0.035 \\
\hline MUFA & 31.905 & 31.486 & 33.605 & 0.614 & $33.920^{\mathrm{a}}$ & $32.294^{\mathrm{ab}}$ & $30.782^{b}$ & 0.752 & 0.395 \\
\hline Other MUFA & $2.014^{\mathrm{a}}$ & $1.537^{\mathrm{b}}$ & $1.588^{\mathrm{b}}$ & 0.081 & $2.092^{\mathrm{A}}$ & $1.600^{\mathrm{B}}$ & $1.446^{\mathrm{B}}$ & 0.111 & 0.205 \\
\hline PUFA & 20.936 & 21.873 & 20.363 & 0.719 & $18.717^{\mathrm{b}}$ & $21.244^{\mathrm{ab}}$ & $23.212^{\mathrm{a}}$ & 0.914 & 0.104 \\
\hline$n-6$ & 15.169 & 15.180 & 13.836 & 0.550 & 13.485 & 14.647 & 16.053 & 0.674 & 0.081 \\
\hline$n-3$ & 4.733 & 5.454 & 5.071 & 0.219 & $4.093^{\mathrm{B}}$ & $5.304^{\mathrm{A}}$ & $5.863^{\mathrm{A}}$ & 0.268 & 0.246 \\
\hline n-3 LC-PUFA & 2.311 & 2.695 & 2.403 & 0.145 & $2.052^{\mathrm{b}}$ & $2.590^{\mathrm{ab}}$ & $2.767^{\mathrm{a}}$ & 0.178 & 0.391 \\
\hline$n-6 / n-3$ & $3.419^{\mathrm{A}}$ & $2.798^{\mathbf{B}}$ & $2.759^{\mathrm{B}}$ & 0.076 & $3.380^{\mathbf{A}}$ & $2.813^{\mathrm{B}}$ & $2.783^{\mathrm{B}}$ & 0.097 & 0.026 \\
\hline IDCLA & 26.591 & 25.140 & 26.268 & 0.570 & $27.927^{\mathrm{A}}$ & $25.599^{\mathrm{AB}}$ & $24.473^{\mathrm{B}}$ & 0.698 & 0.212 \\
\hline ATH & $0.763^{\mathrm{a}}$ & $0.665^{\mathrm{b}}$ & $0.669^{\mathrm{b}}$ & 0.021 & $0.777^{\mathrm{A}}$ & $0.687^{\mathrm{B}}$ & $0.634^{\mathrm{B}}$ & 0.022 & 0.001 \\
\hline THR & 1.045 & 0.954 & 0.955 & 0.025 & $1.088^{\mathrm{A}}$ & $0.969^{\mathrm{B}}$ & $0.898^{\mathrm{B}}$ & 0.031 & 0.054 \\
\hline
\end{tabular}

CTR: diet without extruded linseed; EL-10: diet containing $100 \mathrm{~g} / \mathrm{kg}$ of extruded linseed; EL-20: diet containing $200 \mathrm{~g} / \mathrm{kg}$ of extruded linseed.

SFA: saturated fatty acids.

MUFA: monounsaturated fatty acids.

PUFA: polyunsaturated fatty acids.

n-3 LC-PUFA: n-3 long chain-polyunsaturated fatty acids.

IDCLA: index of the $\Delta 9$-desaturase activity $=$ C18:2 cis 9, trans-11 $\times 100 /$ C18:1 trans- $11+$ C18:2 cis-9, trans-11.

ATH: atherogenicity index $=\mathrm{C} 12: 0+(4 \times \mathrm{C} 14: 0+\mathrm{C} 16: 0) / \mathrm{MUFA}+\mathrm{PUFA}$.

THR: thrombogenicity index $=$ C14:0 + C16:0 + C18:0/(0.5 $\times$ MUFA + 0.5 $\times$ n-6 PUFA $+3 \times n-3$ PUFA + n-3 PUFA/n-6 PUFA $)$.

Tr: traces, under the detectable limits.

Means with different superscript within the same row differ. ${ }^{\mathrm{a}, \mathrm{b}} P<0.05 ;{ }^{\mathrm{A}, \mathrm{B}} P<0.01 ;{ }^{\mathrm{A}, \mathrm{B}, \mathrm{C}} P<0.001$.

in the EL-20 samples (Table 6). This effect was influenced by the presence of seasoning (salt, olive oil, and spices) as well, being samples without seasoning characterised by a higher score for extraneous flavours (2,3 versus 0.2 for samples with or without seasoning, resp.) (Table 6). There are not many reports in the literature showing the effects of dietary linseed on the sensory quality of the cooked lamb meat. As reported by several authors $[45,46]$, the use of dietary n-3 PUFA 
TABLE 6: Effect of lamb postweaning (PW) diet and presence of seasoning (S) on sensory properties of light lamb meat.

\begin{tabular}{|c|c|c|c|c|c|c|c|}
\hline \multirow{2}{*}{ Item } & \multicolumn{2}{|c|}{ CTR } & \multicolumn{2}{|c|}{ EL-20 } & \multirow{2}{*}{ SEM } & \multicolumn{2}{|c|}{$P$} \\
\hline & With seasoning & Without seasoning & With seasoning & Without seasoning & & $\mathrm{PW}$ & S \\
\hline Lamb meat odour & 5.357 & 5.740 & 5.373 & 5.917 & 0.520 & 0.762 & 0.387 \\
\hline Extraneous odour & 1.342 & 2.364 & 1.748 & 3.021 & 0.601 & 0.152 & 0.065 \\
\hline Lamb meat flavour & 5.162 & 4.967 & 5.578 & 5.788 & 0.568 & 0.079 & 0.990 \\
\hline Extraneous flavour & 0.100 & 2.026 & 0.406 & 2.733 & 0.516 & 0.014 & $<0.001$ \\
\hline Overall liking & 7.089 & 5.899 & 6.606 & 5.055 & 0.678 & 0.114 & 0.051 \\
\hline
\end{tabular}

CTR: diet without extruded linseed; EL-20: diet containing $200 \mathrm{~g} / \mathrm{kg}$ of extruded linseed.

Seasoning: salt, olive oil, and spices.

can affect the susceptibility to oxidation of the meat and induce flavours defects. After feeding lambs protected PUFA from sunflower seeds, higher notes for extraneous aroma and flavour and decreased lamb meat typical flavour were reported by Park et al. [47]. In another study, where steers were fed diets containing the same linseed concentration as that used in the present experiment $(0.2 \%$ of $\mathrm{BW})$, a perception of extraneous flavours was recorded [48]. In contrast, lamb steaks obtained from animals that received linseed oil-enriched diet were given the highest scores for lamb flavour and overall liking and the lowest score for "abnormal" lamb flavour [49].

Finally, the sensory properties of meat were affected to variable extent by age, gender, and geographical origin of the assessor (data not shown).

\section{Conclusions}

Nutritionists recommend an increase in the intake of LCPUFA n-3 and CLA, as well as an increase in the ratio of PUFA to SFA and/or in the ALA to C18:2 n-6 ratio in dietary lipids. Results from the present experiment confirm that dietary linseed can effectively modify the lipid composition of lamb meat and increase the amounts of FA with nutraceutical activity.

In addition, the level of EL supplementation in both maternal and lamb feeds appeared to positively affect growth performance, while it did not significantly influence the sensory properties of the meat.

Although the data obtained need further confirmation by molecular biology studies in the ovine species, it is suggested that the nutritional environment in early life provides cues for fetal development and can be crucial for FA metabolism throughout life.

\section{Conflict of Interests}

The authors declare that there is no conflict of interests regarding the publication of this paper.

\section{Acknowledgments}

The authors would like to thank E. Cassetta for helping in laboratory analyses and L. Burani and G. Tenerini for the technical assistance and for care of the animals. This project was sponsored by the Italian Ministry of Agriculture (MIPAAF), DM 293/7303/05.

\section{References}

[1] D. I. Givens, "The role of animal nutrition in improving the nutritive value of animal-derived foods in relation to chronic disease," Proceedings of the Nutrition Society, vol. 64, no. 3, pp. 395-402, 2005.

[2] A. K. Arbex, V. R. Bizarro, J. C. S. Santos et al., "The impact of the essential fatty acids (EFA) in human health," Open Journal of Endocrine and Metabolic Diseases, vol. 5, pp. 98-104, 2015.

[3] E. N. Ponnampalam, A. J. Sinclair, B. J. Hosking, and A. R. Egan, "Effects of dietary lipid type on muscle fatty acid composition, carcass leanness, and meat toughness in lambs," Journal of Animal Science, vol. 80, no. 3, pp. 628-636, 2002.

[4] A. M. Wachira, L. A. Sinclair, R. G. Wilkinson, M. Enser, J. D. Wood, and A. V. Fisher, "Effects of dietary fat source and breed on the carcass composition, n-3 polyunsaturated fatty acid and conjugated linoleic acid content of sheep meat and adipose tissue," British Journal of Nutrition, vol. 88, no. 6, pp. 697-709, 2002.

[5] F. Noci, F. J. Monahan, and A. P. Moloney, "The fatty acid profile of muscle and adipose tissue of lambs fed camelina or linseed as oil or seeds," Animal, vol. 5, no. 1, pp. 134-147, 2011.

[6] E. Jerónimo, S. P. Alves, S. V. Martins, J. A. M. Prates, R. J. B. Bessa, and J. Santos-Silva, "Effect of sodium bentonite and vegetable oil blend supplementation on growth, carcass quality and intramuscular fatty acid composition of lambs," Animal Feed Science and Technology, vol. 158, no. 3-4, pp. 136-145, 2010.

[7] J. de la Fuente-Vázquez, M. T. Díaz-Díaz-Chirón, C. PérezMarcos et al., "Linseed, microalgae or fish oil dietary supplementation affects performance and quality characteristics of light lambs," Spanish Journal of Agricultural Research, vol. 12, no. 2, pp. 436-447, 2014.

[8] E. N. Ponnampalam, P. A. Lewandowski, F. T. Fahri et al., "Forms of n-3 (ALA, C18:3n-3 or DHA, C22:6n-3) fatty acids affect carcass yield, blood lipids, muscle n-3 fatty acids and liver gene expression in lambs," Lipids, vol. 50, no. 11, pp. 1133-1143, 2015.

[9] G. A. Dunn and T. L. Bale, "Maternal high-fat diet promotes body length increases and insulin insensitivity in secondgeneration mice," Endocrinology, vol. 150, no. 11, pp. 4999-5009, 2009.

[10] B. S. Muhlhausler, R. A. Gibson, and M. Makrides, "The effect of maternal omega-3 long-chain polyunsaturated fatty acid (n-3 LCPUFA) supplementation during pregnancy and/or lactation on body fat mass in the offspring: a systematic review of animal 
studies," Prostaglandins Leukotrienes and Essential Fatty Acids, vol. 85, no. 2, pp. 83-88, 2011.

[11] S. P. Hoile, N. A. Irvine, C. J. Kelsall et al., "Maternal fat intake in rats alters 20: 4 n-6 and 22: 6n-3 status and the epigenetic regulation of Fads2 in offspring liver," The Journal of Nutritional Biochemistry, vol. 24, no. 7, pp. 1213-1220, 2013.

[12] M. D. Niculescu, D. S. Lupu, and C. N. Craciunescu, "Perinatal manipulation of $\alpha$-linolenic acid intake induces epigenetic changes in maternal and offspring livers," The FASEB Journal, vol. 27, no. 1, pp. 350-358, 2013.

[13] P. Benatti, G. Peluso, R. Nicolai, and M. Calvani, "Polyunsaturated fatty acids: biochemical, nutritional and epigenetic properties," Journal of the American College of Nutrition, vol. 23, no. 4, pp. 281-302, 2004.

[14] G. Boudry, V. Douard, J. Mourot, J.-P. Lallès, and I. Le HuërouLuron, "Linseed oil in the maternal diet during gestation and lactation modifies fatty acid composition, mucosal architecture, and mast cell regulation of the ileal barrier in piglets," The Journal of Nutrition, vol. 139, no. 6, pp. 1110-1117, 2009.

[15] M. Ebrahimi, M. A. Rajion, G. Y. Meng, A. S. Farjam, E. Oskoueian, and S. Jafari, "Diet high in $\alpha$-linolenic acid upregulate PPAR- $\alpha$ gene expression in the liver of goats," Electronic Journal of Biotechnology, vol. 18, no. 3, pp. 210-214, 2015.

[16] V. Berthelot, P. Bas, E. Pottier, and J. Normand, "The effect of maternal linseed supplementation and/or lamb linseed supplementation on muscle and subcutaneous adipose tissue fatty acid composition of indoor lambs," Meat Science, vol. 90, no. 3, pp. 548-557, 2012.

[17] A. J. F. Russel, J. M. Doney, and R. G. Gunn, "Subjective assessment of body fat in live sheep," The Journal of Agricultural Science, vol. 72, no. 3, pp. 451-454, 1969.

[18] AOAC, Official Methods of Analysis, Association of Official Analytical Chemists, Arlington, Va, USA, 15th edition, 1990.

[19] AOAC, Official Methods of Analysis, Association of Official Analytical Chemists, Arlington, Va, USA, 16th edition, 1996.

[20] K. Julshamn, A. Maage, H. C. Wallin et al., "Determination of magnesium and calcium in foods by atomic absorption spectrometry after microwave digestion: NMKL collaborative study," Journal of AOAC International, vol. 81, no. 6, pp. 12021208, 1998.

[21] AOAC, Official Methods of Analysis, Association of Official Analytical Chemists, Arlington, Va, USA, 17th edition, 2000.

[22] P. J. Van Soest, J. B. Robertson, and B. A. Lewis, "Methods for dietary fiber, neutral detergent fiber, and nonstarch polysaccharides in relation to animal nutrition," Journal of Dairy Science, vol. 74, no. 10, pp. 3583-3597, 1991.

[23] Commission International de l'Eclairage, "Colourimetry: official recommendations of the international commission on illumination," Publication CIE 15 (E-1.3.1), Bureau Central de la Commission Internationale de l'Eclairage, Paris, France, 1976.

[24] R. Branciari, D. Ranucci, C. Forte et al., "Impiego di Saccharomyces cerevisiae nell'alimentazione del pollo da carne: 2 . Effetto su qualità reologica della carne e proprietà sensoriali percepite dal consumatore," Progress in Nutrition, vol. 16, no. 4, pp. 303-309, 2014.

[25] E. G. Bligh and W. J. Dyer, "A rapid method of total lipid extraction and purification," Canadian Journal of Biochemistry and Physiology, vol. 37, no. 8, pp. 911-917, 1959.

[26] R. Branciari, L. Mughetti, D. Ranucci et al., "Influence of manufacturing procedure on the compositional and sensory properties of n-3 fatty acid-enriched pecorino cheese," Journal of Dairy Research, vol. 81, no. 4, pp. 455-461, 2014.
[27] R. Branciari, A. Valiani, M. Trabalza-Marinucci et al., "Consumer acceptability of ovine cheese from ewes fed extruded linseed-enriched diets," Small Ruminant Research, vol. 106, pp. S43-S48, 2012.

[28] SAS, SAS/STAT 9.22 User's. Guide, SAS Institute Inc, Cary, NC, USA, 2010

[29] European Parliament and the Council of the European Union, "Directive 2010/63/ EU of the European Parliament and of the Council of 22 September 2010 on the protection of animals used for scientific purposes," Official Journal of the European Union, vol. 276, pp. 33-79, 2010.

[30] R. Zhang, A. F. Mustafa, and X. Zhao, "Effects of flaxseed supplementation to lactating ewes on milk composition, cheese yield, and fatty acid composition of milk and cheese," Small Ruminant Research, vol. 63, no. 3, pp. 233-241, 2006.

[31] P. Gómez-Cortés, A. Bach, P. Luna, M. Juárez, and M. A. de la Fuente, "Effects of extruded linseed supplementation on n3 fatty acids and conjugated linoleic acid in milk and cheese from ewes," Journal of Dairy Science, vol. 92, no. 9, pp. 41224134, 2009.

[32] B. Gallardo, M. G. Manca, A. R. Mantecón, A. Nudda, and T. Manso, "Effects of linseed oil and natural or synthetic vitamin E supplementation in lactating ewes' diets on meat fatty acid profile and lipid oxidation from their milk fed lambs," Meat Science, vol. 102, pp. 79-89, 2015.

[33] L. Mughetti, G. Acuti, C. Antonini, S. De Vincenzi, O. Olivieri, and M. T. Marinucci, "Effects of feeding raw or extruded linseed on the ruminal ecosystem of sheep," Italian Journal of Animal Science, vol. 6, no. 1, pp. 327-329, 2007.

[34] L. Mughetti, F. Sinesio, G. Acuti et al., "Integration of extruded linseed into dairy sheep diets: effects on milk composition and quality and sensorial properties of Pecorino cheese," Animal Feed Science and Technology, vol. 178, no. 1-2, pp. 27-39, 2012.

[35] S. C. Kim, A. T. Adesogan, L. Badinga, and C. R. Staples, "Effects of dietary n-6:n-3 fatty acid ratio on feed intake, digestibility, and fatty acid profiles of the ruminai contents, liver, and muscle of growing lambs," Journal of Animal Science, vol. 85, no. 3, pp. 706-716, 2007.

[36] E. Jerónimo, S. P. Alves, J. A. M. Prates, J. Santos-Silva, and R. J. B. Bessa, "Effect of dietary replacement of sunflower oil with linseed oil on intramuscular fatty acids of lamb meat," Meat Science, vol. 83, no. 3, pp. 499-505, 2009.

[37] M. Korotkova, B. Gabrielsson, M. Lönn, L.-Å. Hanson, and B. Strandvik, "Leptin levels in rat offspring are modified by the ratio of linoleic to $\alpha$-linolenic acid in the maternal diet," Journal of Lipid Research, vol. 43, no. 10, pp. 1743-1749, 2002.

[38] L. H. Allen, "Nutritional influences on linear growth: a general review," European Journal of Clinical Nutrition, vol. 48, supplement 1, pp. S75-S89, 1994.

[39] A. P. Moloney, C. Kennedy, F. Noci, F. J. Monahan, and J. P. Kerry, "Lipid and colour stability of M. longissimus muscle from lambs fed camelina or linseed as oil or seeds," Meat Science, vol. 92, no. 1, pp. 1-7, 2012.

[40] C. Vieira, A. Fernández-Diez, J. Mateo, R. Bodas, S. Soto, and T. Manso, "Effects of addition of different vegetable oils to lactating dairy ewes' diet on meat quality characteristics of suckling lambs reared on the ewes' milk," Meat Science, vol. 91, no. 3, pp. 277-283, 2012.

[41] W.-S. Choo, J. Birch, and J.-P. Dufour, "Physicochemical and quality characteristics of cold-pressed flaxseed oils," Journal of Food Composition and Analysis, vol. 20, no. 3-4, pp. 202-211, 2007. 
[42] S. M. Kitessa, A. Williams, S. Gulati, V. Boghossian, J. Reynolds, and K. L. Pearce, "Influence of duration of supplementation with ruminally protected linseed oil on the fatty acid composition of feedlot lambs," Animal Feed Science and Technology, vol. 151, no. 3-4, pp. 228-239, 2009.

[43] C. J. Kelsall, S. P. Hoile, N. A. Irvine et al., "Vascular dysfunction induced in offspring by maternal dietary fat involves altered arterial polyunsaturated fatty acid biosynthesis," PLOS ONE, vol. 7, no. 4, Article ID e34492, 2012.

[44] M. Ebrahimi, M. A. Rajion, Y. M. Goh, A. Q. Sazili, and J. T. Schonewille, "Effect of linseed oil dietary supplementation on fatty acid composition and gene expression in adipose tissue of growing goats," BioMed Research International, vol. 2013, Article ID 194625, 11 pages, 2013.

[45] G. Gandemer, "Lipides du muscle et qualité de la viande. Phospholipides et flaveur," Oleagineux-Corps Gras-Lipides, vol. 4, pp. 19-25, 1997.

[46] G. Zervas and E. Tsiplakou, "The effect of feeding systems on the characteristics of products from small ruminants," Small Ruminant Research, vol. 101, no. 1-3, pp. 140-149, 2011.

[47] R. J. Park, A. L. Ford, and D. Ratcliffe, "Effect on meat flavour of period of feeding a protected lipid supplement to lambs," Journal of Food Science, vol. 40, no. 6, pp. 1217-1221, 1975.

[48] S. L. Kronberg, E. J. Scholljegerdes, A. N. Lepper, and E. P. Berg, "The effect of flaxseed supplementation on growth, carcass characteristics, fatty acid profile, retail shelf life, and sensory characteristics of beef from steers finished on grasslands of the northern Great Plains," Journal of Animal Science, vol. 89, no. 9, pp. 2892-2903, 2011.

[49] G. R. Nute, R. I. Richardson, J. D. Wood et al., "Effect of dietary oil source on the flavour and the colour and lipid stability of lamb meat," Meat Science, vol. 77, no. 4, pp. 547-555, 2007. 

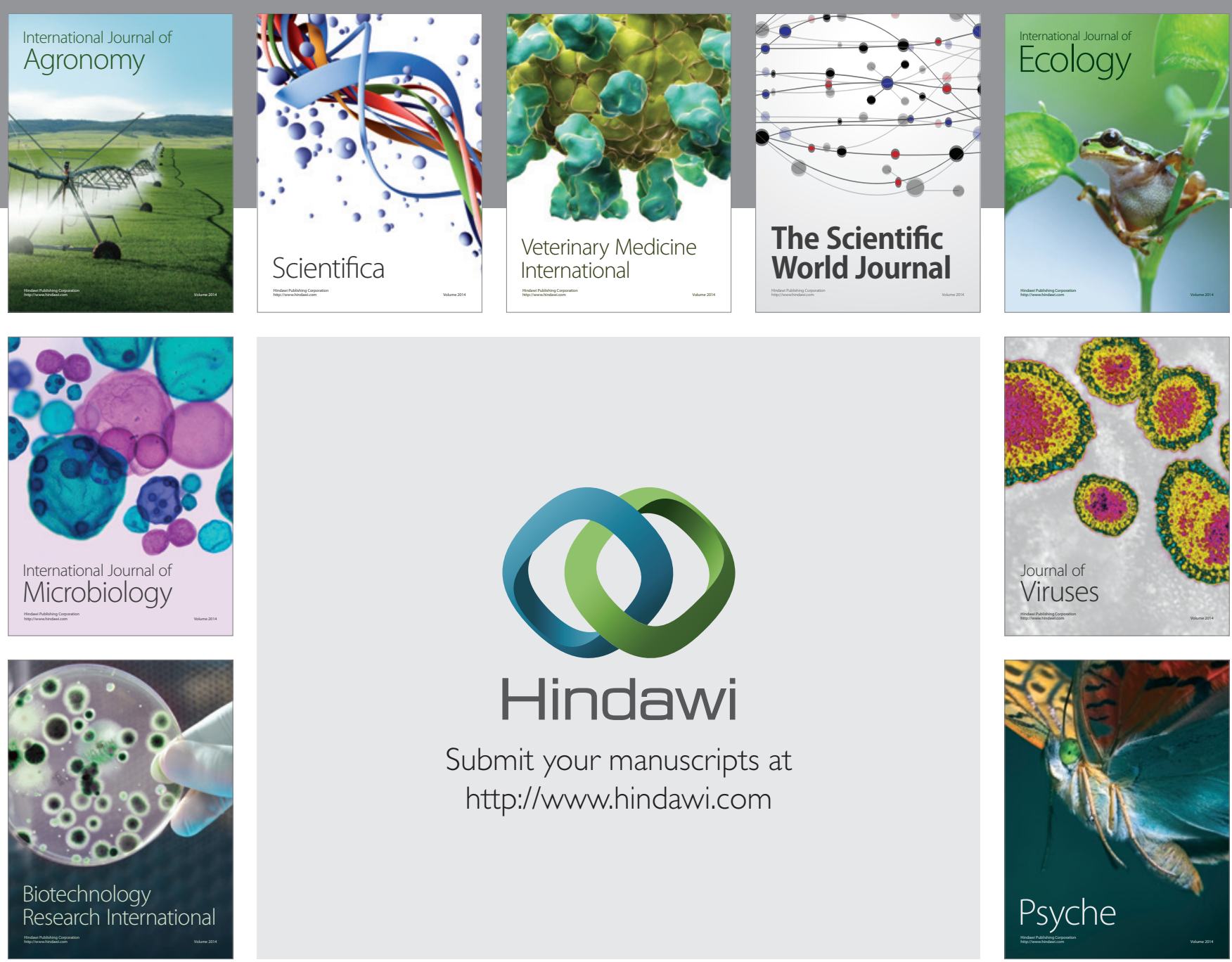

Submit your manuscripts at

http://www.hindawi.com
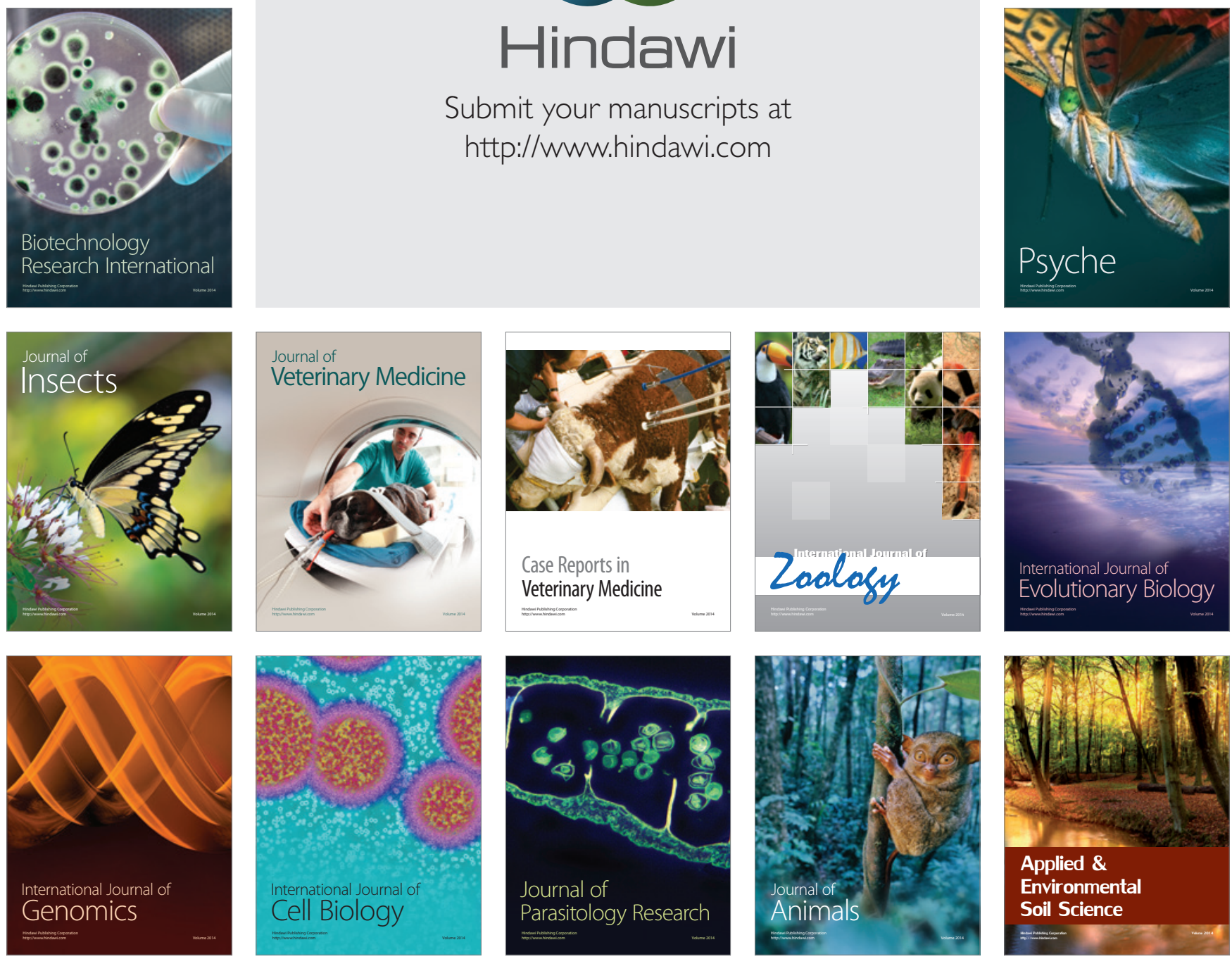